\title{
0 médico e o paciente: breve história de uma relação delicada
}

José Carlos Ismael

Prof. Dr. Zacaria Borge

Ali RAMADAm ${ }^{1}$

\section{Resumo}

A relação médico-paciente é disciplina obrigatória em todas as melhores faculdades de medicina do mundo, objetivando habilitar o futuro médico a ter um desempenho satisfatório e pertinente com os enfermos, de modo a reforçar a tarefa terapêutica através de uma relação segura, confiável e positiva. Centenas de obras de autores médicos foram publicadas a respeito, sob o enfoque desses profissionais.

Outras tantas, escritas por pacientes, quase todas no plano da literatura ficcional, muitas delas geniais, refletem particularidades, ressentimentos, frustrações emocionais e outras distorções quase caricatas, ora dos médicos, ora dos pacientes, seja superdimensionando uma ou outra, não contribuem para uma adequada avaliação do problema.

Esta obra, produzida por um respeitado intelectual de grande erudição, que, durante muitos anos foi paciente e dependeu de orientações médicas das mais diversas, surpreende pelo seu equilíbrio e ponderação.

Inicia-se com o depoimento de vários professores de medicina das mais importantes universidades do País a respeito do assunto, quase todos manifestando insatisfação ou desconforto a respeito. Segue-se uma exaustiva revisão, desde os procedimentos mágicos xamanísticos da pré-história, passando pela medicina hipocrática e galênica, com a instauração dos modelos racionais na medicina, através de Vesalius, Falopius e outros luminares; adentra nas questões da linguagem e comunicação, nos aspectos psicológicos, psicanalíticos e também discute personagens clássicos da literatura de ficção. Os títulos dos capítulos são bastante sugestivos da profundidade com que o tema é tratado: "A escalada do homem”; "A tableteca de Assurbanipal”; “Asclépios e a compaixão”; "Hipócrates e a razão”; “Galeno e o determinismo divino”; "Cristianismo e retrocesso"; "Paracelso e a devoção”; "Vesálio e a reinvenção do corpo”; “O nascimento do paciente"; "Comunicação, o problema”; "O pa-ciente médico"; "Confortar, escutar, olhar, tocar"; "Envolver-se ou não, eis a questão"; "Medicalização da vida e bioética”; “A morte no horizonte”.

$O$ autor oferece resultados de sua pesquisa informal com numerosos outros pacientes, sobre suas expectativas em relação à figura do médico, e complementa sua obra com um apêndice que reproduz o código de ética médica. O livro, publicado em dezembro de 2002, resultado de muita pesquisa e informação bibliográfica, é leitura indispensável para todos os médicos e estudantes de medicina.

Recebido: 03/03/2004 - Aceito: 08/03/2004

1 Professor-associado e Chefe do Departamento de Psiquiatria da Faculdade de Medicina da Universidade de São Paulo - FMUSP

Endereço para correspondência: Instituto de Psiquiatria, Hospital das Clínicas da Faculdade de Medicina da Universidade de São Paulo (HC-FMUSP), Rua Ovídio Pires de Campos, 785, $3^{\circ}$ andar - Cep 05403-010 - email: zramadam@usp.br 